\title{
The Past, Present, and Future of Demand-Driven Acquisitions in Academic Libraries
}

\section{Edward A. Goedeken and Karen Lawson}

\begin{abstract}
Demand-driven acquisitions (DDA) programs have become a wellestablished approach toward integrating user involvement in the process of building academic library collections. However, these programs are in a constant state of evolution. A recent iteration in this evolution of ebook availability is the advent of large ebook collections whose contents libraries can lease, but not own only if they choose to do so. This study includes an investigation of patron usage and librarian ebook selection by comparing call number data generated by usage of three entities: (1) an ebrary PDA; (2) Academic Complete, which is a leased collection of ebooks; and (3) subject librarian selections based on the YPB approval plan at lowa State University. The context is provided through a description of the development and evolution of demand driven acquisitions programs with an analysis of where libraries have been and where they are going with enhancing the collection development in academic libraries.
\end{abstract}

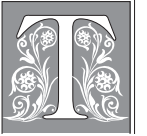

wenty-five years ago, Futas and Vidor raised the question of what "constitutes a good collection." ${ }^{11}$ Although more than two decades have passed, creating a collection that effectively meets the needs of its patrons remains a core challenge for any library, academic or public. Since the days of Callimachus and the Alexandrian Library, librarians have often struggled to build collections for not only their contemporaries, but also for those individuals who will explore the collection's contents in decades or centuries to come. ${ }^{2}$ Over the years, diligent collection development librarians endeavored to create a balance between the exhaustiveness suggested by the seventeenth-century French bibliographer Gabriel Naudé, who observed that there was not a book "whatsoever, be it never so bad or disparaged, but may in time be sought for by someone," and the more modern belief of Yale librarian Andrew Keogh, who averred that the "number of volumes in a library means little more than their cubage or their weight; it is appropriateness, it is quality, that counts."3

To assist with the daunting task of keeping pace with the deluge of publishing that accelerated during the years following the Second World War, librarians sought to manage the selection process through the newly invented approval plan approach. The

Edward A. Goedeken is Professor of Library and Information Science and Karen Lawson is Associate Professor and Associate Dean, Collections E Technical Services, in Parks Library at Iowa State University; e-mail: goedeken@iastate.edu, klawson@iastate.edu. (C) 2015 Edward A. Goedeken and Karen Lawson 
approval plan was first developed in 1962 by Richard Abel for Washington State University at Pullman. Abel's company went out of business in the mid-1970s, but the idea of a structured approval plan managed by an outside vendor that would cover the major subjects and publishers more efficiently than library staff soon became an established practice for many academic libraries. ${ }^{4}$ During the last quarter of the twentieth century, librarians developed a comprehensive set of best practices and guidelines to assist them in the selection and acquisition of materials they believed best fit their patrons' needs. ${ }^{5}$ This "just in case" approach to collection development presented problems, however. Trueswell discovered in 1969 that 20 percent of a typical academic library's collection generated about 80 percent of circulation. Low circulation rates were also revealed in Kent's classic 1979 study, and further echoed by a 2010 Cornell University report that noted 55 percent of its monographs acquired since 1990 had never circulated. ${ }^{6} \mathrm{~A}$ recent 2010 comparative analysis of approval book circulation at the University of Illinois at Urbana-Champaign and Pennsylvania State University showed a significant percentage of the materials acquired never left the shelf. ${ }^{7}$ Moreover, a recent study estimated that the cost of maintaining an individual book in the open stacks for the long term could amount to over $\$ 140$ per volume. ${ }^{8}$ Thus libraries were acquiring books that did not circulate, while spending thousands of dollars keeping them on the shelves.

In recent decades, libraries have been adjusting to the shifting of journals from print to electronic, with the traditional printed monograph now following the same path. Indeed, as one writer noted, the "tectonic plates are on the move," and everyone in the publishing chain, from publishers to booksellers to vendors to libraries had to adaptand quickly." ${ }^{9}$ For example, EBSCO Information Services reported that between 1999 and 2011, EBSCO's revenue from electronic resources of all types rose from 4 percent to 63 percent ${ }^{10}$ - a significant increase in a short time period.

The challenge of creating an effective and appropriate library collection has been further tested by the recent advent of what Clayton Christensen has termed "disruptive technology." In his well-known study The Innovator's Dilemma, Christensen explores the impact of technological change on the business and other communities. ${ }^{11}$ For Christensen, technology can either be sustaining or disruptive. Sustaining technologies improve the performance of products and continue to make them valuable to the consumer. Disruptive technologies, on the other hand, initially underperform in the marketplace but have a tendency to improve their quality at a rapid rate and eventually replace the established technology. ${ }^{12}$ The result, as Henry Lucas noted, was that the customer benefited greatly from "more choice, more flexibility, more options." ${ }^{13}$ For libraries, the availability of electronic books (e-books) that can be accessed outside the traditional catalog via a patron-driven or demand-driven process (DDA) is indeed disruptive to the entire fabric of established collection development procedures. ${ }^{14}$

Over the past couple of centuries, libraries have developed sophisticated bibliographic structures to accommodate the printed book and its acquisition, description, and classification. In the space of two decades, however, this well-established arrangement has been shaken by the disruptive technology of the DDA. This phenomenon has upended (perhaps in a good way) the approach to building collections that librarians - particularly academic librarians - had created after gaining control of selection from the teaching faculty in the 1960s. ${ }^{15}$ (It should be noted that the term PDA or DDA has evolved over time, and for purposes here we will use the term DDA to represent patron involvement in contemporary collection development whether it be through a PDA or a DDA.)

Through the DDA, the users - unbeknownst to them - suddenly have emerged as a player in building academic library collections. They have become, as Suzanne Ward recently noted, a new partner in collection development. ${ }^{16}$ For decades, librarians filled their shelves with materials based on what the librarians determined would best meet patrons' 
needs. ${ }^{17}$ As this century's second decade began, however, prominent library thinkers, such as Rick Anderson, concluded that the DDA would become "the standard approach for most research libraries." ${ }^{18}$ And, as Sandler recently noted, today's librarians need to do a better job of knowing "all they can about our users" and their actual information needs. ${ }^{19}$

With a DDA in place, e-book titles that have immediate usage can be incorporated directly into a library's permanent collection. But, in practice, how do the titles that patrons access during their online catalog investigations compare with those chosen consciously by the professional library selector? Do patrons and librarians identify the same materials, or are there differences in what is chosen? We conducted a study at the Iowa State University (ISU) Library to investigate how e-books added to our collection through our DDA compared with titles chosen by the professional librarians.

\section{Literature Review}

For the past two decades, libraries have sought to-as the authors of a University of Iowa study recently stated - "Give 'Em What They Want." ${ }^{20}$ Instead of trying to determine what patrons needed, libraries began to obtain materials at the point of demand. This new approach reflected the appearance of three separate trends that converged toward the end of the twentieth century, each complementing the other. The availability of books in electronic format steadily increased as pressure from the reading public forced publishers to provide more of their output to be viewed electronically. ${ }^{21}$ Concomitantly, through various loading mechanisms, libraries were able to provide records for these electronic versions in their local catalogs, thus providing seamless and instantaneous access to the electronic text. This technical advancement in access represented a profound change in the relationship between the selector and the user, at the same time providing useful data that collection managers could analyze to improve the collection. ${ }^{22}$ Added to this dynamic mix was a final ingredient: the growing use of electronic media by the undergraduate student, who is actively engaged with various mobile devices delivering instant access to information of all sorts. ${ }^{23}$

DDA programs have had a relatively short lifespan in libraries, yet by the end of this century's first decade they had become well-known enough in academic circles to garner coverage in the Chronicle of Higher Education. ${ }^{24}$ Moreover, in 2011, two separate collections of articles about DDAs were published. Judith Nixon and her fellow editors compiled a set of essays that had originally been published in a 2010 issue of Collection Management and were reprinted the next year as Patron-Driven Acquisitions: Current Successes and Future Directions. In the introduction, Nixon, Freeman, and Ward survey the history of DDA and how it evolved from being based on interlibrary loan requests to the current arrangement whereby a library loads records for e-books into its online catalog or discovery system, whose purchase is then triggered by patron use. ${ }^{25}$ Patron-Driven Acquisitions is divided into three sections, with the first part devoted to articles that describe how interlibrary loan was used as the basis for acquiring books. The second part includes essays pertinent to the present study, with two contributions by Hodges, Preston and Hamilton on the role of e-books in libraries, and a summary of how the University of Denver had implemented a DDA by Levine-Clark. ${ }^{26}$ The final section of the book includes an article by Reynolds and her colleagues on Texas A\&M Library's DDA experience, and a chapter by Bracke, Hérubel, and Ward with their reflections on what the DDA means for the traditional collection development librarian. ${ }^{27}$

The other volume of essays is edited by David A. Swords and titled Patron-Driven Acquisitions: History and Best Practices. Of particular interest are the two beginning essays by Lugg and Nardini. Lugg provides a contextual framework with a thoughtprovoking review of the DDA as a "disruptive technology" to traditional library services. Nardini, who has had a long career working for various monograph vendors, 
conducts an overview of the approval plan and its role in collection development over the past forty years. ${ }^{28}$ Additional essays include Swords' discussion of the impact of the DDA on publishers and publishing and an historical summary of patron-driven acquisitions by Polanka and Delquié. Dillon, who has worked with e-books at the University of Texas, shares his experienced perspective on how to control costs when implementing a patron-driven program..$^{29}$ These two essay collections include a large number of important assessments of the DDA and provide a valuable starting point for any investigation of this new approach to collection development.

More essays on DDA are contained in two recent issues of Against the Grain. In June 2011, a series of articles introduced by Arch, who wonders whether everyone has "tired of hearing about patron-driven acquisitions yet?," includes observations by Johnson on the various purchasing options available, Price's assessment of DDA and its impact on digital rights management, and Levine-Clark's explanation of his model for longterm management of e-books acquired by DDAs. In the same issue, Spitzform reviews University of Vermont's DDA program with generally positive results. ${ }^{30}$

Against the Grain revisited the DDA approach in 2012 with new essays by Dinkins, who described Stetson University's DDA experience and compared circulation data on titles placed in the catalog by librarians versus those chosen by the teaching faculty. Dinkins concluded that the librarian-selected titles were chosen for purchase more often, but the titles added by the teaching faculty ultimately showed more patron usage. Elmore compared the cost per usage of e-books acquired by an approval plan with the cost per usage of e-books obtained via DDA and discovered that these ebooks generated a lower cost per usage. Welch and Koch showed how they sought to blend print and e-book acquisitions at Drake University in an effort to expand patron access to a larger universe of content. ${ }^{31}$ These and other studies touch on the question of how patron-selected versus librarian-selected materials compare in circulation. A recent article on this topic - though focused primarily on print materials-provides a thorough and extensive literature review. ${ }^{32}$ As 2013 progressed, reports of DDA use continued to appear with Mays' comparison of circulation/usage statistics for print versus electronic titles acquired by a DDA and Wood's observations about the difference between patron immediate information needs and library collection's long-term goals. ${ }^{33}$

In addition to the studies noted above, other assessments that could be called metaanalyses should be noted. One of the most comprehensive is Walters' detailed investigation of more than a dozen DDA experiments that took place over the past several years. He presents a sophisticated analysis of these efforts and expresses concern about the long-term effects of libraries using DDAs to build collections. Walters is dubious that patrons choosing materials to solve immediate information needs represents the best approach toward creating a collection that is enduring and appropriate for the expectations of future researchers. ${ }^{34}$ Sens and Fonseca echo Walters' concerns and wonder if libraries have leaped onto the demand-driven bandwagon without sufficient consideration of its impact on the long-term collection. ${ }^{35}$ Another study, which anticipates our current investigation in some respects, created lists of patron-chosen titles and asked the librarian selectors to indicate which of those same titles they would have chosen. The authors concluded that, in many cases, the patrons and the librarians often chose titles of the same level of sophistication and usefulness. ${ }^{36}$

The foregoing literature review shows both the extent of investigations into the new world of DDA, as well as the concerns, ably expressed by Walters, about the long-term impact patron-driven selections could have on academic collections. In many respects, this is the crux of the issue when libraries entertain the idea of implementing a DDA. When it comes to building a long-lasting collection, how much should any academic library rely on patrons using the immediate triggering mechanism of a DDA? 


\section{Methodology}

Over the years, librarians have conducted various studies of how printed books circulate, comparing those that were firm-ordered with those suggested by patrons or obtained automatically through approval plans. ${ }^{37}$ DDAs have become increasingly commonplace, as are the newly emerging large leased collections: patrons' involvement in building electronic monograph collections is becoming business as usual. However, professional librarians continue to select titles for their local library collections as they have done for years, with the only change being with the format selected. We investigated how the relationship between the DDA, the leased e-book collection, and the traditional selection of subject librarians would compare based on LC subject classification. We wanted to find out how closely our patron usage of e-books matched those subject areas selected by our subject librarians. We also were interested in finding out whether the DDA generated more activity than the leased e-book collections.

Until 2010, the Iowa State University Library's purchase of e-books had taken place through its monograph vendor, YBP Library Services. The library also has an approval plan with YBP. The approval plan automatically ships only printed titles, and e-books are selected by the librarians from notification slips. In early 2010, the library began to participate in e-brary's DDA plan as a way of increasing access to e-books beyond our YBP printed book profile. Since e-books were a new format for our library to acquire, we initially focused our investigation on a comparison of titles selected by librarians with those triggered for addition to the collection by users. We added a new dimension to our study when our library began subscribing to e-brary's Academic Complete database. Academic Complete is a leased product that provides access to electronic books but does not allow patron use to trigger a purchase for permanent retention in the collection. ${ }^{38}$ The idea of a leased book collection has been around for years, with Brodart's McNaughton Collection being one of the more well-known approaches. However, the McNaughton Collection only deals with printed books and media material and has yet to include e-books in its offerings. ${ }^{39}$ By including Academic Complete's database in our study, we realized we could broaden our investigation by including use of this new leased collection for comparison with the other two approaches. To date, little research had been conducted on the usage of leased collections such as e-brary's Academic Complete or EBSCOhost's eBook Academic Collection, but their existence creates a new vehicle for patron access to published electronic information.

To build its Academic Complete database, e-brary uses an in-house team of librarians who assess each title for its professional and scholarly focus, as well as other factors such as publisher reputation and depth of content. For its DDA, e-brary allows the participating library to shape its basic list and establish limits for price, content, and publication date. ${ }^{40}$ At the outset, ISU set limits for price (no more than \$150) and the publication date limited to the most recent two years as the basis for inclusion in the plan. Popular fiction was also excluded. ISU used e-brary's standard criteria for determining when patron use "triggered" an automatic purchase for the library. ${ }^{41}$

- 10 pages viewed in a single browser session

- 10 minutes of viewing in a single browser session

- 1 print of any page

- 1 download of any page

Within a short time, further sculpting of the DDA became necessary. Users were triggering a number of Wiley's Dummies book series, and they were then excluded from the pool of eligible content. During this same period, McGraw-Hill decided to suddenly remove their e-books content from e-brary's offerings. Despite these initial challenges, ISU's records show that the number of titles that publishers made available in our e-brary DDA grew from 7,000 titles in June 2010 to more than 42,000 in 
October 2012. It appears that publishers were quickly realizing that participating in a DDA meant the possibility of more sales.

In addition to firm orders, Academic Complete, and the DDA, ISU uses YPB's approval plan as another source for e-books. Although print publications are the default value for our approval plan, librarian selectors have the ability to choose an electronic version of any available title. For the most part, YBP's GOBI database maintains the most recent two years of e-books, although there are occasions when a publisher produced an electronic version of an older title several years after its initial publication.

In a DDA program, the "selectors" are unknown. They could be members of the faculty, a distance learner, or a first-year undergraduate. How do their choices compare to what the librarian selector chooses for the collection? The authors examined data collected during a 22-month period (October 2010-July 2012). During the review period, 7,489 titles were available to users via e-brary's DDA, and an additional 7,707 were available through Academic Complete. The results use the Library of Congress (LC) classification schedule to compare the number of titles ISU Library users triggered for the collection via the DDA or accessed for viewing via the leased collection with the titles selected by ISU subject librarians. The LC classification schedule is widely used throughout the United States as a standard approach to organizing print collections by subject. Although electronic books do not need a classification number, one is assigned by YBP and e-brary for each title in their collections. There are other ways the data could have been analyzed, including by publisher or by date, but the LC call number comparison provides the clearest and simplest comparative scheme.

\section{Results and Discussion}

During the period under review, 15,196 titles were made available for selection by users through e-brary's DDA $(7,489)$ and their Academic Complete $(7,707)$ leased collection. Thirteen percent $(n=969)$ of available e-brary DDA titles were triggered for purchase and four percent $(n=340)$ of Academic Complete titles reflected some level of usage. These percentages are relatively small but do indicate that, at least early in the implementation of these programs, users were not draining the library's collection budget. Careful sculpting of the programs' profiles with price limits, noninclusion of specific publishers, or elimination of popular materials can assist in users' choices being restricted to operate within collection policies suitable for an academic library. As selectors and administrators grow more comfortable with these programs, restrictions can be eased and the profiles adjusted.

Comparison of the numbers of titles selected or triggered is summarized in table 1, which consists of five columns. The first column represents the LC classification, followed by columns for titles that patrons triggered in e-brary and accessed in Academic Complete. The total number of titles for columns 2 and 3 is represented in the fourth column, which provides of total of all patron activity. The table concludes with a column for number of titles selected by the subject librarian. Overall, 43 percent $(n=1,309)$ titles were chosen by users via a DDA program, and 57 percent $(n=1,720)$ were selected by librarians.

One hundred thirty-nine (139) LC classification ranges of one or more class letters were used for e-books either by a DDA program or when chosen by a librarian. Twenty-six percent $(n=36)$ of the class ranges were used only via a DDA program. Of the classification ranges used exclusively for DDA titles, 78 percent $(n=28)$ were social sciences/humanities titles, and 22 percent $(n=8)$ were science/technology titles. Table 2 summarizes the data in the science/technology classification areas $(\mathrm{Q}, \mathrm{R}, \mathrm{S}, \mathrm{T})$ and shows that 37 percent $(n=580)$ of the titles were triggered or accessed by patrons and 63 percent $(n=1,005)$ were chosen by librarians. 
The Past, Present, and Future of Demand-Driven Acquisitions 211

\begin{tabular}{|c|c|c|c|c|}
\hline \multicolumn{5}{|c|}{$\begin{array}{c}\text { TABLE } 1 \\
\text { Subject Classification Analysis by Patron Usage and Selector Decisions }\end{array}$} \\
\hline LC Class & ebrary & $\begin{array}{l}\text { Academic } \\
\text { Complete }\end{array}$ & $\begin{array}{c}\text { Demand- } \\
\text { Driven Total }\end{array}$ & Selector \\
\hline B & 0 & 3 & 3 & 7 \\
\hline $\mathrm{BD}$ & 3 & 0 & 3 & 2 \\
\hline $\mathrm{BF}$ & 22 & 6 & 28 & 4 \\
\hline $\mathrm{BH}$ & 0 & 0 & 0 & 1 \\
\hline BJ & 1 & 1 & 2 & 0 \\
\hline $\mathrm{BL}$ & 6 & 1 & 7 & 8 \\
\hline $\mathrm{BM}$ & 0 & 2 & 2 & 1 \\
\hline $\mathrm{BP}$ & 1 & 2 & 3 & 1 \\
\hline BQ & 1 & 0 & 1 & 1 \\
\hline $\mathrm{BR}$ & 0 & 0 & 0 & 2 \\
\hline $\mathrm{BS}$ & 12 & 8 & 20 & 2 \\
\hline $\mathrm{BT}$ & 4 & 0 & 4 & 2 \\
\hline $\mathrm{BV}$ & 2 & 0 & 2 & 1 \\
\hline $\mathrm{BX}$ & 3 & 1 & 4 & 1 \\
\hline Total & 55 & 24 & 79 & 33 \\
\hline $\mathrm{CC}$ & 1 & 0 & 1 & 0 \\
\hline $\mathrm{CN}$ & 0 & 1 & 1 & 0 \\
\hline $\mathrm{CS}$ & 1 & 0 & 1 & 0 \\
\hline $\mathrm{CT}$ & 0 & 0 & 0 & 1 \\
\hline Total & 2 & 1 & 3 & 1 \\
\hline $\mathrm{D}$ & 0 & 2 & 2 & 2 \\
\hline $\mathrm{DC}$ & 1 & 0 & 1 & 1 \\
\hline DD & 2 & 0 & 2 & 0 \\
\hline DF & 2 & 1 & 3 & 0 \\
\hline DG & 3 & 2 & 5 & 0 \\
\hline DS & 10 & 1 & 11 & 1 \\
\hline DT & 0 & 0 & 0 & 1 \\
\hline DU & 0 & 1 & 1 & 0 \\
\hline Total & 18 & 7 & 25 & 5 \\
\hline $\mathbf{E}$ & 7 & 14 & 21 & 75 \\
\hline $\mathbf{F}$ & 7 & 7 & 14 & 25 \\
\hline
\end{tabular}




\begin{tabular}{|c|c|c|c|c|}
\hline \multicolumn{5}{|c|}{$\begin{array}{c}\text { TABLE } 1 \\
\text { Subject Classification Analysis by Patron Usage and Selector Decisions }\end{array}$} \\
\hline LC Class & ebrary & $\begin{array}{l}\text { Academic } \\
\text { Complete }\end{array}$ & $\begin{array}{c}\text { Demand- } \\
\text { Driven Total }\end{array}$ & Selector \\
\hline G & 7 & 3 & 10 & 13 \\
\hline GA & 1 & 0 & 1 & 0 \\
\hline GB & 1 & 1 & 2 & 3 \\
\hline GC & 0 & 0 & 0 & 3 \\
\hline GE & 2 & 1 & 3 & 4 \\
\hline GF & 2 & 0 & 2 & 2 \\
\hline GN & 7 & 2 & 9 & 7 \\
\hline GR & 0 & 0 & 0 & 4 \\
\hline GT & 1 & 0 & 1 & 5 \\
\hline $\mathrm{GV}$ & 13 & 7 & 20 & 87 \\
\hline Total & 34 & 14 & 48 & 128 \\
\hline $\mathrm{H}$ & 5 & 0 & 5 & 6 \\
\hline HA & 5 & 1 & 6 & 1 \\
\hline HB & 8 & 5 & 13 & 23 \\
\hline $\mathrm{HC}$ & 6 & 0 & 6 & 47 \\
\hline HD & 41 & 13 & 54 & 75 \\
\hline HE & 4 & 2 & 6 & 1 \\
\hline $\mathrm{HF}$ & 37 & 9 & 46 & 24 \\
\hline HG & 22 & 1 & 23 & 18 \\
\hline HJ & 1 & 0 & 1 & 1 \\
\hline HM & 11 & 0 & 11 & 3 \\
\hline $\mathrm{HN}$ & 4 & 0 & 4 & 2 \\
\hline HQ & 20 & 16 & 36 & 41 \\
\hline HT & 8 & 7 & 15 & 9 \\
\hline $\mathrm{HV}$ & 7 & 11 & 18 & 7 \\
\hline HX & 0 & 1 & 1 & 0 \\
\hline Total & 179 & 66 & 245 & 258 \\
\hline JA & 3 & 0 & 3 & 0 \\
\hline $\mathrm{JC}$ & 1 & 1 & 2 & 0 \\
\hline $\mathrm{JF}$ & 2 & 1 & 3 & 0 \\
\hline JK & 3 & 2 & 5 & 0 \\
\hline $\mathrm{JN}$ & 2 & 0 & 2 & 0 \\
\hline JV & 0 & 3 & 3 & 2 \\
\hline $\mathrm{JZ}$ & 9 & 0 & 9 & 0 \\
\hline
\end{tabular}


The Past, Present, and Future of Demand-Driven Acquisitions 213

\begin{tabular}{|c|c|c|c|c|}
\hline \multicolumn{5}{|c|}{$\begin{array}{c}\text { TABLE } 1 \\
\text { Subject Classification Analysis by Patron Usage and Selector Decisions }\end{array}$} \\
\hline LC Class & ebrary & $\begin{array}{l}\text { Academic } \\
\text { Complete }\end{array}$ & $\begin{array}{c}\text { Demand- } \\
\text { Driven Total }\end{array}$ & Selector \\
\hline Total & 20 & 7 & 27 & 2 \\
\hline $\mathrm{K}$ & 2 & 1 & 3 & 3 \\
\hline $\mathrm{KD}$ & 1 & 0 & 1 & 0 \\
\hline $\mathrm{KF}$ & 5 & 5 & 10 & 5 \\
\hline KFC & 0 & 1 & 1 & 0 \\
\hline KFX & 0 & 1 & 1 & 0 \\
\hline $\mathrm{KL}$ & 0 & 1 & 1 & 0 \\
\hline $\mathrm{KNC}$ & 1 & 0 & 1 & 0 \\
\hline Total & 9 & 9 & 18 & 8 \\
\hline LA & 2 & 1 & 3 & 12 \\
\hline LB & 49 & 4 & 53 & 64 \\
\hline $\mathrm{LC}$ & 16 & 0 & 16 & 28 \\
\hline LD & 0 & 1 & 1 & 1 \\
\hline LJ & 0 & 1 & 1 & 1 \\
\hline Total & 67 & 7 & 74 & 106 \\
\hline ML & 9 & 1 & 10 & 11 \\
\hline MT & 5 & 0 & 5 & 6 \\
\hline Total & 14 & 1 & 15 & 17 \\
\hline $\mathrm{N}$ & 8 & 0 & 8 & 4 \\
\hline NA & 9 & 5 & 14 & 3 \\
\hline $\mathrm{NC}$ & 3 & 0 & 3 & 2 \\
\hline ND & 2 & 0 & 2 & 0 \\
\hline NK & 3 & 0 & 3 & 0 \\
\hline $\mathrm{NX}$ & 1 & 0 & 1 & 1 \\
\hline Total & 26 & 5 & 31 & 10 \\
\hline $\mathrm{P}$ & 22 & 9 & 31 & 4 \\
\hline PA & 2 & 0 & 2 & 0 \\
\hline $\mathrm{PC}$ & 10 & 2 & 12 & 0 \\
\hline $\mathrm{PE}$ & 14 & 2 & 16 & 0 \\
\hline $\mathrm{PJ}$ & 3 & 2 & 5 & 0 \\
\hline PL & 1 & 0 & 1 & 0 \\
\hline
\end{tabular}




\begin{tabular}{|c|c|c|c|c|}
\hline \multicolumn{5}{|c|}{$\begin{array}{c}\text { TABLE } 1 \\
\text { Subject Classification Analysis by Patron Usage and Selector Decisions }\end{array}$} \\
\hline LC Class & ebrary & $\begin{array}{l}\text { Academic } \\
\text { Complete }\end{array}$ & $\begin{array}{c}\text { Demand- } \\
\text { Driven Total }\end{array}$ & Selector \\
\hline $\mathrm{PN}$ & 19 & 3 & 22 & 19 \\
\hline PQ & 2 & 1 & 3 & 3 \\
\hline PR & 7 & 0 & 7 & 2 \\
\hline PS & 4 & 4 & 8 & 11 \\
\hline PT & 1 & 1 & 2 & 1 \\
\hline Total & 85 & 24 & 109 & 40 \\
\hline Q & 4 & 5 & 9 & 18 \\
\hline QA & 91 & 34 & 125 & 166 \\
\hline QB & 2 & 0 & 2 & 55 \\
\hline $\mathrm{QC}$ & 15 & 6 & 21 & 190 \\
\hline QD & 9 & 11 & 20 & 51 \\
\hline QE & 4 & 0 & 4 & 12 \\
\hline $\mathrm{QH}$ & 21 & 16 & 37 & 53 \\
\hline QK & 6 & 3 & 9 & 1 \\
\hline $\mathrm{QL}$ & 8 & 5 & 13 & 33 \\
\hline QM & 2 & 0 & 2 & 0 \\
\hline $\mathrm{QP}$ & 17 & 3 & 20 & 34 \\
\hline $\mathrm{QR}$ & 6 & 5 & 11 & 1 \\
\hline Total & 185 & 88 & 273 & 614 \\
\hline $\mathrm{R}$ & 5 & 1 & 6 & 4 \\
\hline RA & 8 & 7 & 15 & 17 \\
\hline $\mathrm{RB}$ & 2 & 0 & 2 & 0 \\
\hline $\mathrm{RC}$ & 37 & 8 & 45 & 14 \\
\hline $\mathrm{RD}$ & 7 & 1 & 8 & 1 \\
\hline $\mathrm{RE}$ & 4 & 0 & 4 & 0 \\
\hline RF & 1 & 0 & 1 & 0 \\
\hline $\mathrm{RG}$ & 1 & 0 & 1 & 0 \\
\hline $\mathrm{RJ}$ & 4 & 2 & 6 & 13 \\
\hline $\mathrm{RM}$ & 7 & 1 & 8 & 5 \\
\hline RT & 2 & 0 & 2 & 0 \\
\hline Total & 78 & 20 & 98 & 54 \\
\hline $\mathrm{S}$ & 4 & 4 & 8 & 35 \\
\hline SB & 10 & 9 & 19 & 45 \\
\hline
\end{tabular}


The Past, Present, and Future of Demand-Driven Acquisitions 215

\begin{tabular}{|c|c|c|c|c|}
\hline \multicolumn{5}{|c|}{$\begin{array}{c}\text { TABLE } 1 \\
\text { Subject Classification Analysis by Patron Usage and Selector Decisions }\end{array}$} \\
\hline LC Class & ebrary & $\begin{array}{l}\text { Academic } \\
\text { Complete }\end{array}$ & $\begin{array}{c}\text { Demand- } \\
\text { Driven Total }\end{array}$ & Selector \\
\hline SD & 0 & 0 & 0 & 3 \\
\hline SF & 11 & 5 & 16 & 1 \\
\hline $\mathrm{SH}$ & 0 & 0 & 0 & 7 \\
\hline SK & 0 & 0 & 0 & 1 \\
\hline Total & 25 & 18 & 43 & 92 \\
\hline $\mathrm{T}$ & 7 & 3 & 10 & 17 \\
\hline TA & 19 & 5 & 24 & 99 \\
\hline TD & 2 & 2 & 4 & 0 \\
\hline TE & 0 & 0 & 0 & 1 \\
\hline $\mathrm{TF}$ & 0 & 1 & 1 & 0 \\
\hline $\mathrm{TH}$ & 12 & 2 & 14 & 0 \\
\hline $\mathrm{TJ}$ & 4 & 0 & 4 & 2 \\
\hline TK & 46 & 4 & 50 & 62 \\
\hline TL & 11 & 0 & 11 & 21 \\
\hline $\mathrm{TN}$ & 1 & 0 & 1 & 6 \\
\hline $\mathrm{TP}$ & 11 & 4 & 15 & 10 \\
\hline TR & 15 & 1 & 16 & 6 \\
\hline $\mathrm{TS}$ & 4 & 0 & 4 & 7 \\
\hline TT & 3 & 1 & 4 & 3 \\
\hline TX & 6 & 2 & 8 & 11 \\
\hline Total & 141 & 25 & 166 & 245 \\
\hline $\mathrm{U}$ & 5 & 2 & 7 & 1 \\
\hline UA & 1 & 1 & 2 & 0 \\
\hline UG & 0 & 0 & 0 & 2 \\
\hline Total & 6 & 3 & 9 & 3 \\
\hline Z & 11 & 0 & 11 & 4 \\
\hline Total & 11 & $\mathbf{0}$ & 11 & 4 \\
\hline Grand Total & 969 & 340 & 1,309 & 1,720 \\
\hline
\end{tabular}




\begin{tabular}{|l|c|c|c|c|}
\hline \multicolumn{5}{|c|}{ TABLE 2 } \\
\hline LC Class & ebrary & $\begin{array}{c}\text { Academic } \\
\text { Complete }\end{array}$ & $\begin{array}{c}\text { Demand- } \\
\text { Driven Total }\end{array}$ & Selector \\
\hline Q & 185 & 88 & 273 & 614 \\
\hline R & 78 & 20 & 98 & 54 \\
\hline S & 25 & 18 & 43 & 92 \\
\hline T & 141 & 25 & 166 & 245 \\
\hline Total & 429 & 151 & 580 & 1,005 \\
\hline
\end{tabular}

In similar fashion, table 3 summarizes the social sciences/humanities classification areas $(\mathrm{B}-\mathrm{H}, \mathrm{J}-\mathrm{N}, \mathrm{P}, \mathrm{U}, \mathrm{Z})$ where 50.4 percent $(\mathrm{n}=729)$ of the titles were triggered or accessed by patrons and 49.6 percent $(n=715)$ were selected by librarians.

TABLE 3

Social Sciences/Humanities Classification Areas

\begin{tabular}{|l|c|c|c|c|}
\hline LC Class & ebrary & $\begin{array}{c}\text { Academic } \\
\text { Complete }\end{array}$ & $\begin{array}{c}\text { Demand- } \\
\text { Driven Total }\end{array}$ & Selector \\
\hline B & 55 & 24 & 79 & 33 \\
\hline C & 2 & 1 & 3 & 1 \\
\hline D & 18 & 7 & 25 & 5 \\
\hline E & 7 & 14 & 21 & 75 \\
\hline F & 7 & 7 & 14 & 25 \\
\hline G & 34 & 14 & 48 & 128 \\
\hline H & 179 & 66 & 245 & 258 \\
\hline J & 20 & 7 & 27 & 2 \\
\hline K & 9 & 9 & 18 & 8 \\
\hline L & 67 & 7 & 74 & 106 \\
\hline M & 14 & 1 & 15 & 17 \\
\hline N & 26 & 5 & 31 & 10 \\
\hline P & 85 & 24 & 109 & 40 \\
\hline U & 6 & 3 & 9 & 3 \\
\hline Z & 11 & 0 & 11 & 4 \\
\hline Totals & 540 & 189 & 729 & 715 \\
\hline
\end{tabular}

One of the inherent complexities in analyzing this comparative data is that each source of titles represents a different subset of what is available. Table 1 shows that, in every broad LC class except United States History (E), the e-brary DDA generated more user choice than titles offered by Academic Complete. Similarly, one can see in table 3 that in the majority of classes the subject librarian selected more titles than those used by patrons via Academic Complete. For the sciences and technology classes shown in table 3, it is clear that the librarian selector chose nearly twice as many titles as the patrons. Within classes, there are occasions where Academic Complete reflects more 
use-such as in HV - than either e-brary DDA or subject librarian activity, but these instances are rare. For the most part, it appears that the titles in the e-brary DDA or in the YBP approval profile seemed to fit the library's collection needs more often than what was used in Academic Complete.

In answer to our question about how closely patron activity matched that of the librarian selectors, we can see that it varies between the social sciences/humanities and the science/technology areas. Table 2 (science/technology) shows a significant difference between the number of titles selected by librarians and those accessed or triggered by patrons. Table 3 (social sciences/humanities), on the other hand, reveals quite similar totals for the number of titles chosen by librarians and those accessed or triggered by patrons. Since the vendors provide lists of the specific titles that are accessed/triggered or selected by librarians, further research could delve more deeply into analyzing these microdecisions at a title-by-title level.

Our second question concerned the level of activity each of our patron e-book platforms generated. From tables 2 and 3, we can see that, overall, the e-brary DDA attracted more patron attention than the leased collection. This has implications that require future exploration. The DDA places titles permanently in a library's collection, while the leased arrangement does not. Once again, our research was not detailed enough to investigate at the title level what e-books were triggered by the DDA and what e-books attracted usage in the leased collection. It is possible that libraries could sculpt their DDA to contain titles within specific class ranges, thus allowing the patron to help build the local collection in areas that are acknowledged strengths, while at the same time incorporating the broader leased collection to meet patron demands for topical areas outside the library's main collecting foci.

For collection development librarians, these sorts of data can quickly reveal areas where there is a discrepancy between the librarian's deliberative selection approach and that of the patron filling an immediate information need. Herein lies one of the key challenges for librarians: as trained informational professionals, they often take a longer view of the collection and its role in supporting the institution's educational mission. Thus they take into account not only the current academic environment, but also how the library has supported that subject area in the past. They also have developed relationships with the departmental faculty and colleges and know the institution's larger strategic goals. On the other hand, the patron is seeking information that solves an immediate problem or project, and any long-term research goals they may have are often not represented by the items they choose today.

The implementation of a DDA program changes the nature of collection development. It is one thing to cede some measure of control over book selection to carefully crafted approval plans. The library literature is replete with warnings about the trend toward disintermediation or outsourcing. ${ }^{42}$ Given this difference between short-term patron information needs and the longer view that librarians must take to responsibly build enduring library collections, comparative data generated by patrons versus librarians must be analyzed carefully to make sure that the library selector is not overly influenced by temporal decisions driven by short-term information needs. There is still very much a place for the selector librarian who is well versed in his or her subject and clearly understands the institution's mission. Academic library collections are built for not only today's users, but for those who need resources 10, 20, 50, or 100 years from now.

Through their engagement with the library's discovery system, users are unaware that their actions in accessing e-books via a DDA will now can compel a library to acquire that item for its collection with the attending budgetary implications. Library selectors and administrators work with finite budgets. They are very aware of the 
programs within a university and with the funding allocations the library has made in support of each program. Selectors' individual budgets might already include the costs attached to the approval plans in their subject areas. When a library decides to support a DDA program, the funding is allocated from somewhere. The most likely source for this funding is to carve it out from what is possibly already limited funding for monographic resources. It may be a difficult choice to reallocate funds toward experiments, including permutations of DDA programs. By its very nature, a DDA program can show an immediate return on investment. Establishing a baseline budget, documenting how the money is being spent, and being able to demonstrate a return on investment is necessary to show the value of any new program.

Our study focused specifically on how our library treated e-books, which is admittedly a subset of our library's overall collection development efforts. Future research could broaden our investigation to include the acquisition of print volumes and compare them with our growing e-book collection to see if subject patterns differ depending on format. Additionally, it would prove useful to compare circulation patterns for print vs. electronic monographs to determine if electronic books generated more activity than the printed versions.

\section{Conclusion}

Libraries have become relatively comfortable with the involvement of users becoming unknowing partners in collection development through the various DDA vehicles. Our profession has sought to balance the traditional selection approach of professional librarians with the additional contribution of short-term patron needs through DDA. The impact of the relatively new idea of making available large leased e-book collections through such entities as Academic Complete presents an entirely novel approach to collection development. DDA programs may be a disruptive technology, but patron involvement in building library collections is a disruptive innovation. We recognize that our investigation reflects only one academic library's experience with providing access to electronic books. But DDAs are becoming increasingly common in all types of libraries along with the growth of leased collections such as e-brary's Academic Complete becoming part of the library landscape. Our methodology would be simple to replicate and could provide some useful information for those libraries that maintain these multiple approaches to providing access to electronic books. As an innovative disruptive technology, increasing easy patron access to e-book content is here to stay.

As stated previously, Sandler observes that librarians should know all they can about their library's users and their information needs. ${ }^{43}$ While a 2013 Pew Internet study on library services focuses for the most part on public libraries, its statistics can be generalized to the library user population at large.$^{44}$ Regardless of library type, users are keen to browse the shelves for books or media. The Pew study found that "Almost three-quarters (73 percent) of library patrons in the past 12 months say they visit to browse the shelves for books or media." Additionally, of those 25 percent of Americans who went to a library website in the past twelve months, " $82 \%$ of them searched the library catalog for books (including audiobooks and ebooks), CDs, and DVDs." This is good news for libraries that use DDA plans whether they are public or academic. If a library is able to offer a rental collection of 70,000, or 100,000, or even a million titles for its users to browse through, this is an enormously valuable service to provide. In the past, users were able to browse the collection we owned; they are now able to browse a collection to which we can provide access.

S.R. Ranganathan's first law of library science declares "Every reader his book" and the second law asserts "Every book its reader." 45 At the time he was writing, Ranganathan was referring to printed books, yet his "law" remains very much true in the digital world as well. Although technically not "selectors" for the library, the titles 
that patrons trigger through their usage result in the same action as that of a selector: a title will be added to the collection. The impact of large leased collections, such as that represented by Academic Complete, represents a profound change in the amount of material a library can make available to patrons at minimal cost. As such, these large leased collections demonstrate anew the disruptive power of digital information to our traditional approaches to collection development. For at least 2,000 years, since the codex superseded papyrus as the format of choice, librarians have coped with and adapted to an array of technological innovations. Librarians will always attempt to meet the challenge of providing information and access to our users in whatever format is most relevant at the time. The electronic book simply represents one of the most recent technological developments for collection development in libraries. How well we respond to technology that is both disruptive and innovative will be a major determinant in the continued relevance of academic library collections in our educational future.

\section{Notes}

1. Elizabeth Futas and David L. Vidor, "What Constitutes a Good Collection?" Library Journal 112, no. 7 (Apr. 15, 1987): 45-47.

2. On Callimachus and the Alexandrian Library, see The Library of Alexandria: Centre of Learning in the Ancient World, ed. Roy MacLeod (London: I.B. Tauris Publishers, 2000); and Lionel Casson, Libraries in the Ancient World (New Haven: Yale University Press, 2001), 31-47.

3. Gabriel Naudé, Advice on Establishing a Library (Berkeley: University of California Press, 1950), 17 (This is an English translation of Naudé's original 1644 Advis pour Dresser une Bibliothèque); Andrew Keogh, "Address" in Addresses at the Dedication of the Sterling Memorial Library at Yale University on 11 April 1931 (New Haven: Yale University Press, 1931), 134.

4. Abel's account is found in his "The Origin of the Library Approval Plan," Publishing Research Quarterly 11, no. 1 (1995), 46-56. A useful short summary is by Ann L. O'Neill, "How the Richard Abel Co., Inc. Changed the Way We Work," Library Acquisitions: Practice \& Theory 17, no. 1 (1993), 41-46.

5. A good overview of collection development views during the late 1970s can be found in Collection Development in Libraries: A Treatise, 2 vols., eds. Robert D. Stueart and George B. Miller, Jr. (Foundations in Library and Information Science, v. 10). See also Peggy Johnson, "Collection Development in the Best of Times and the Worst of Times," Commemorating the Past, Celebrating the Present, Creating the Future, Papers in Observance of the 50th Anniversary of the Association for Library Collections \& Technical Services, ed. Pamela Bluh (Chicago: American Library Association), 75-94.

6. Cornell University Task Force on Print Collection Usage, Report of the Collection Development Executive Committee Task Force on Print Collection Usage (Ithaca: Cornell University Libraries, 2010), 2, available online at http://staffweb.library.cornell.edu/system/files/CollectionUsageTF_ReportFinal11-22-10.pdf [accessed 10 March 2013].

7. Richard L. Trueswell, "Some Behavioral Patterns of Libraries: The 80/20 Rule," Wilson Library Bulletin 43, no. 5 (1969), 458-61; Allen Kent et al., Use of Library Materials: The University of Pittsburgh Study (New York: M. Dekker, 1979). In addition to the Cornell University study already noted, see also the University of Illinois/Penn State study by Robert Alan et al., "Approval Plan Profile Assessment in Two Large ARL Libraries: University of Illinois at Urbana-Champaign and Pennsylvania State University," Library Resources \& Technical Services 54, no. 2 (Apr. 2010), 64-76.

8. Paul N. Courant and Matthew "Buzzy" Nielsen, "On the Cost of Keeping a Book," in The Idea of Order: Transforming Research Collections for 21st Century Scholarship (June 2010) (Washington, D.C.: Council on Library and Information Resources, 2010), 91.

9. Frances Pinter, "Development of Book Publishing Business Models and Finances," in Academic and Professional Publishing, eds. Robert Campbell, Ed Pentz, and Ian Borthwick (Oxford: Chandos Publishing, 2012), 190.

10. Allen Powell, "Navigating the New Norm: Vendor, Publisher, and Librarian Strategies to Cope with the Changing Information Industry," Journal of Library Administration 52, no. 5 (2012): 377.

11. The full title is The Innovator's Dilemma: When New Technologies Cause Great Firms to Fail (Boston, Mass.: Harvard Business School Press, 1997).

12. Christensen's theories are summarized in Erwin Danneels, "Disruptive Technology Re- 
considered: A Critique and Research Agenda," Journal of Product Innovation Management 21 (2004), 246-58.

13. Henry C. Lucas, Jr., The Search for Survival: Lessons from Disruptive Technologies (Santa Barbara, Calif.: Praeger, 2012), 9.

14. David W. Lewis has discussed the impact of disruptive technology in libraries in two recent articles: "The Innovator's Dilemma: Disruptive Change and Academic Libraries," Library Administration \& Management 18 (Spring 2004): 68-74; and "The Inevitability of Open Access," College \& Research Libraries 73 (Sept. 2012): 493-506.

15. The history of postwar collection development, especially for the period 1945-1979, is provided by David E. Jones, "Collection Growth in Postwar America: A Critique of Policy and Practice," Library Trends 61, no. 3 (2013): 587-612.

16. Suzzane M. Ward, "Patrons: Your New Partners in Collection Development," American Libraries 45, no. 3/4 (2014): 13.

17. Bill Katz reviews the traditional role of the collection development librarian in "Book Selection and Collection Building: Evolution of the Art," in Recruiting, Educating, and Training Librarians for Collection Development, eds. Peggy Johnson and Sheila S. Intner (Westport, Conn.: Greenwood Press, 1994): 3-16. An historical assessment of selection can be found in John D. Haskell, Jr., "Subject Bibliographers in Academic Libraries: An Historical and Descriptive Review," Advances in Library Administration and Organization 3 (1984): 73-84.

18. Rick Anderson, "Collections 2021: The Future of the Library Collection Is Not a Collection," Serials 24, no. 3 (2011), 213.

19. Mark Sandler, "Collection Development in the Age-Day of Google," Library Resources \& Technical Services 50, no. 4 (2006): 242.

20. Karen S. Fischer et al., "Give 'Em What They Want: A One-Year Study of Unmediated Patron-Driven Acquisition of e-Books," College \& Research Libraries 73, no. 5 (2012): 469-92.

21. For a history of the e-book, see Laura Manley and Robert P. Holley, "History of the Ebook: The Changing Face of Books," Technical Services Quarterly v. 29, no.4 (2012): 292-311. Also informative is a brief survey by Marie Lebert, A Short History of Ebooks (Project Gutenberg, 2009), available online at www.gutenberg.org/etext/29801. A survey of contemporary e-book use in libraries can be found in Ebooks in Libraries: A Practical Guide, eds. Kate Price and Virginia Havergal (London: Facet Publishing, 2011).

22. Faye A. Chadwell, “What's Next for Collection Management and Managers? User-Centered Collection Management," Collection Management 34, no. 2 (2009): 69.

23. Tracey Wilen-Daugenti, Society 3.0: How Technology Is Reshaping Education, Work and Society (New York: Peter Lang, 2012), 108. See also Howard Gardner and Katie Davis, The App Generation: How Today's Youth Navigate Identity, Intimacy, and Imagination in a Digital World (New Haven: Yale University Press, 2013).

24. Jennifer Howard, "Reader Choice, Not Vendor Influence, Reshapes Library Collections," Chronicle of Higher Education 57, no. 12 (Nov. 12, 2010), A11-A12.

25. Judith M. Nixon, Robert S. Freeman, and Suzanne M. Ward, "An Introduction and Literature Review," in Patron-Driven Acquisitions: Current Successes and Future Directions, eds. Judith M. Nixon, Robert S. Freeman, and Suzanne M. Ward (New York: Routledge, 2011), 1-6. (Hereafter cited as Nixon, Freeman, and Ward, Patron-Driven Acquisitions).

26. Dracine Hodges, Cyndi Preston, and Marsha J. Hamilton, "Resolving the Challenge of E-Books," in Nixon, Freeman, and Ward, Patron-Driven Acquisitions, 78-82; Hodges, Preston, and Hamilton, "Patron-Initiated Collection Development: Progress of a Paradigm Shift," in Nixon, Freeman, and Ward, Patron-Driven Acquisitions, 90-103; Michael Levine-Clark, "Developing a Multiformat Demand-Driven Acquisition Model," in Nixon, Freeman, and Ward, Patron-Driven Acquisitions, 83-89. Levine-Clark expanded on this topic with his recent "Building a DemandDriven Collection: The University of Denver Experience," in Patron-Driven Acquisitions: History and Best Practices, ed. David A. Swords (Boston: Walter de Gruyter, 2011), 45-60.

27. Leslie J. Reynolds et al., "User-Driven Acquisitions: Allowing Patrons to Drive Collection Development in an Academic Library," in Patron-Driven Acquisitions, 126-36; Marianne Stowell Bracke, Jean-Pierre V.M. Hérubel, and Suzanne M. Ward, "Some Thoughts on Opportunities for Collection Development Librarians," in Patron-Driven Acquisitions, 137-41.

28. Rick Lugg, "Collecting for the Moment: Patron-Driven Acquisitions as a Disruptive Technology," in Patron-Driven Acquisitions: History and Best Practices, ed. David A. Swords (Boston: Walter de Gruyter, 2011), 7-22; Bob Nardini, "Approval Plans and Patron Selection: Two Infrastructures," in Patron-Driven Acquisitions: History and Best Practices, ed. David A. Swords (Boston: Walter de Gruyter, 2011), 23-43. (Swords book will be cited hereafter as Swords, Patron-Driven Acquisitions).

29. David Swords, "PDA and Publishers," in Swords, Patron-Driven Acquisitions, 107-16; Sue Polanka and Emilie Delguié, "Patron-Driven Business Models: History, Today's Landscape, and Opportunities," in Swords, Patron-Driven Acquisitions, 119-35; Dennis Dillon, "Texas Demand- 
Driven Acquisitions: Controlling Costs in a Large-Scale PDA Program," in Swords, Patron-Driven Acquisitions, 157-67.

30. Xan Arch, "Patron-Driven Acquisitions," Against the Grain 23, no. 1 (2011): 1; Robert Johnson, "Purchasing Options in Patron-Driven Acquisitions," Against the Grain 23, no. 1 (2011): 14, 16; Jason Price, "Patron-Driven Acquisition of Publisher-Hosted Content: Bypassing DRM," Against the Grain 23, no. 1 (2011): 16, 18, 20; Michael Levine-Clark, "Developing a Model for Long-Term Management of Demand-Driven Acquisitions," Against the Grain 23, no. 1 (2011): 24, 26; Peter Spitzform, "Patron-Driven Acquisition: Collecting as if Money and Space Mean Something," Against the Grain 23, no. 1 (2011): 20, 22, 24.

31. Debbi Dinkins, "Who Chooses Wisely? ebook PDA Purchases: Librarian and Teaching Faculty Selections," Against the Grain 24, no. 6 (2012): 14, 16, 18, 20; Dara Elmore, "A Study of the Demand-Driven Acquisition of eBook Titles in an Academic Library," Against the Grain 24, no. 6 (2012): 20, 22; Andrew Welch and Teri Koch, "Patron-Driven Acquisitions: Integrating Print Books with eBooks," Against the Grain 24, no. 6 (2012): 26, 28.

32. David C. Tyler et al., "Patron-Driven Acquisition and Circulation at an Academic Library: Interaction Effects and Circulation Performance of Print Books Acquired via Librarians' Orders, Approval Plans, and Patrons' Interlibrary Loan Requests," Collection Management 38, no. 1 (2013): 3-32.

33. Antje Mays, "Biz of Acq-PDA, Circulation, and Over-Budget Requests: Harnessing Data to Inform Library Strategies," Against the Grain 25, no. 1 (2013): 65-69; Aaron Wood, "Mainstream Patron-Driven Acquisition: Topicality Over the Scholarly Record ... and the Cello Suites," Against the Grain 25, no. 5 (Nov. 2013): 22.

34. William H. Walters, "Patron-Driven Acquisition and the Educational Mission of the Academic Library," Library Resources \& Technical Services 56, no. 3 (2012): 199-213.

35. Jean-Mark Sens and Anthony J. Fonseca, "A Skeptic's View of Patron-Driven Acquisitions: Is It Time to Ask the Tough Questions?" Technical Services Quarterly 30, no. 4 (2013), 359-71.

36. Lisa Shen et al., "Head First into the Patron-Driven Acquisition Pool: A Comparison of Librarian Selections versus Patron Purchases," Journal of Electronic Resources Librarianship 23, no. 3 (2011): 203-18.

37. A recent example is David C. Tyler et al., "Patron-Driven Acquisition and Circulation at an Academic Library: Interaction Effects and Circulation Performance of Print Books Acquired via Librarians' Orders, Approval Plans, and Patrons' Interlibrary Loan Requests," Collection Management 38, no. 1 (2013): 3-32. Also useful, though a bit older, is Justin Littman and Lynn Silipigni Connaway, "A Circulation Analysis of Print Books and E-Books in an Academic Research Library," Library Resources \& Technical Services 48, no. 4 (2004): 256-62.

38. For a description of Academic Complete, see Charlie Remy, "ebrary Academic Complete," The Charleston Advisor 14, no. 2 (Oct. 2012): 21-25. 2014.

39. E-mail communication from Sarah Flock, Brodart representative, to author, January 6 ,

40. E-mail communication to the author from Kelli Gonzalez, ebrary representative, December 20, 2012.

41. ebrary Support Center, available online at http://support.ebrary.com/kb/triggerable-usage/ [accessed 17 April 2013].

42. American Library Association, "Outsourcing and Privatization in Libraries: Select Bibliography," available online at www.ala.org/tools/outsourcing/outsourcingprivatization [accessed 18 February 2013].

43. Sandler, "Collection Development in the Age-Day of Google."

44. Kathryn Zickuhr, Lee Rainie, and Kristen Purcell, "Library Services in the Digital Age" (Pew Research Center's Internet \& American Life Project), available online at http://libraries. pewinternet.org/2013/01/22/Library-services/ [accessed 11 March 2013]. These authors reported in a new study published in March 2014 that 28 percent of adults 18 and over were reading ebooks. Zickuhr, Rainie, and Purcell, "From Distant Admirers to Library Lovers - and Beyond: A Typology of Public Library Engagement in America (Pew Research Center), available online at http://libraries.pewinternet.org/2014/03/13/typology/ [accessed 13 March 2014].

45. S.R. Ranganathan, The Five Laws of Library Science (Madras, India: The Madras Library Association, 1931). 